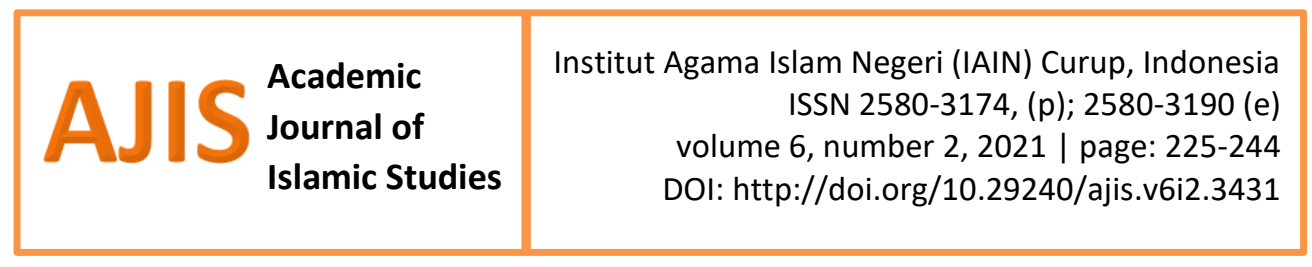

\title{
Learning Islam from Da'i Mualaf: From Curiosity to Strengthen Religious Identity
}

\author{
Stepanus Sigit Pranoto \\ Universitas Islam Negeri (UIN) Sunan Kalijaga, Yogyakarta, Indoneisa \\ sspranoto86@gmail.com
}

\begin{abstract}
This article is part of a study on religious discourse in the new media era. The main study discussed here is how the public access to da'wah content on social media delivered by da'i mualaf. Using a virtual ethnography method, this research studies and analyzes some da'wah content on the YouTube social media platform. The results of this study show that there are a variety of people's motivations in accessing da'wah content, including curiosity about the story of the conversion of the da'i mualaf, which in turn affirms their religious identity as a Muslim. This research also showed a variety of public expression shown in a variety of comments, among other support, criticism, and even theological debate.
\end{abstract}

Keywords: social media da'wah, da'i mualaf, religious conversion, cyber sphere

\section{Introduction}

On November 7, 2019 the detikcom news channel ran news about a number of celebrities who had changed religions that year. Under the title "Artis-artis yang Kabar Pindah Agamanya Bikin Heboh di 2019",1 this popular online news channel displays the profiles of 5 celebrities who in 2019 received the public attention, not because of their work, but because of their decision to change religions. Meanwhile, in 2019 the Liputan6.com news channel contained 17 articles and 1 video containing the topic of Deddy Corbuzier, a celebrity who converted from Catholicism to Islam. ${ }^{2}$ This is a fantastic amount for a news channel that "does not

1 English Translation: "Artists who made an uproar in 2019 because of their religious conversion". See Komario Bahar, "Artis-Artis Yang Kabar Pindah Agamanya Bikin Heboh Di 2019," accessed October 19, 2020, https://hot.detik.com/celeb/d4776066/artis-artis-yang-kabar-pindah-agamanya-bikin-heboh-di2019?_ga=2.210545558.2006997945.1603072772-1064796533.1603072772.

2 See: Liputan 6, "Berita Deddy Corbuzier Masuk Islam Hari Ini - Kabar Terbaru Terkini | Liputan6.Com," accessed October 19, 2020, https://www.liputan6.com/tag/deddy-corbuzier-masuk-islam. 
work for any political interest and stands above and for all groups, and is non-partisan" as they claim on their profile. ${ }^{3}$

Apart from these two news channels, a number of similar news channels can also be found easily on other Indonesian news channels. With the help of the Google search engine, we can find many news about a person's conversion that the public can access through various news channels. It can be said that at the individual level, religious identity, as Casanova said, is not something private, but rather public. ${ }^{4}$ For news service providers, stories about the conversion of a person, especially a famous person, can increase the rating of visitors and readers. Therefore, they try to present such news to benefit their channel. For them, the more people read and visit the channel, the greater the chance of getting a profit because it will be increasingly in demand by advertisers.

In addition, the news about religious conversions in recent years of social media, especially YouTube, has also increasingly been colored by the presence of mualaf - or people who converted to Islam, who became religious preachers. Henceforth, I will use the term " $d a^{\prime} i$ mualaf" to refer to these religious preachers with converts' backgrounds. These $d a^{\prime} i$ mualaf conduct religious preaching or da'wah, both offline through lectures in groups, and online via YouTube channels. In this article, I will pay attention to the second method used, which is about da'i mualaf who convey preaching through YouTube channels. One of the interesting things is that many of them have gained popularity with such a large audience. In this case, they become part of the new da'wah actors involved in the production and reproduction of Islamic discourse in news media. Referring to Noorhaidi Hasan's idea, these new actors can be categorized as creative and fresh agents in the formation of public Islam. ${ }^{5}$

3 See: Liputan 6, “Tentang Kami," accessed October 19, 2020, https://www.liputan6.com/info/tentang-kami.

${ }^{4}$ José Casanova, Public Religions in the Modem World (Chicago: The University of Chicago Press, 1994).

5 Noorhaidi Hasan, "The Making of Public Islam: Piety, Agency, and Commodification on the Landscape of the Indonesian Public Sphere," Contemporary Islam 3, no. 3 (2009): 229-50. 
In recent years, research related to social media da'wah seems to focus on the figure of the preacher, the content and strategy of da'wah. ${ }^{6}$ Meanwhile, attention to public access to social media da'wah is still very rare. Therefore, to fill the void, this research will focus on public access to social media da'wah, especially those delivered by da'i mualaf. By examining public access to social media da'wah, the contribution of this research lies in the evaluative aspect of da'wah methods and strategies in the era of social media.

This article will focus on people's access to the da'i mualaf da'wah, not on the figures or their da'wah strategies. However, the figure of $d a^{\prime} i$ mualaf and their conversion stories will be discussed to get an overview of the situation. The questions raised in this article are: What are the people's motivations for accessing online da'wah conveyed by $d a^{\prime} i$ mualaf? How is the public interest in accessing online da'wah conveyed by da'i mualaf? The answers to these questions are expected to provide an overview of people's motivation in accessing online da'wah conveyed by da'i mualaf. In addition, it will also obtain an overview of the religious behavior of the community in the era of social media.

In answering these questions, I used a qualitative research methodology with a virtual ethnographic method. As defined by Hine, this virtual ethnographic method is a methodology that can be used to investigate the internet and explore entities (users) when using the internet. ${ }^{7}$ Through this method, an overview of the activities of the community who access the preaching of da'i mualaf on social media will be obtained. In this case, YouTube accounts that are used by da'i mualaf as message sender are cultural artifacts that form or are formed by the

6 For example: Wai Weng Hew, "The Art of Dakwah: Social Media, Visual Persuasion and the Islamist Propagation of Felix Siauw," Indonesia and the Malay World 46, no. 134 (2018): 61-79; Suharto and Nurunnisa Mutmainna, "Dakwah Di Media Sosial Daring: Tinjauan Ceramah Khalid Basalamah Di YouTube," Al-Mishbah 14, no. 2 (2018): 191-203; Martin Slama, "A Subtle Economy of Time: Social Media and the Transformation of Indonesia's Islamic Preacher Economy," Economic Anthropology 4, no. 1 (May 22, 2017): 94-106; Eva F Nisa, "Social Media and the Birth of an Islamic Social Movement: ODOJ (One Day One Juz) in Contemporary Indonesia," Indonesia and the Malay World 46, no. 134 (March 20, 2018): 24-43.

7 See: Christine Hine, Virtual Ethnography (London: Sage Publications, Inc., 2000), 2,4,14. 
culture itself. The interactions that occur between entities can be seen in the comment's column, the "like", "dislike" and "subscribe" buttons that are available on each content. There we will get an overview of the activities that take place in the social media space which are also cultural artifacts.

In support of this virtual ethnographic method, I distributed a questionnaire to a number of people through the Google Form service. From the questionnaires that were distributed randomly, there were 22 respondents who answered them. The answers to this questionnaire mainly helped me in mapping out the preachers who were widely accessed by the respondents. Among the names mentioned, there were two names that I finally chose as a study, namely Ustadz Felix Siauw and Ustadz Steven Indra Wibowo. These names were chosen because many respondents mentioned them.

The behavior of netizens towards the presence of da'i mualaf is traced from two examples of da'wah videos containing their conversion stories, which will be taken from the Felix Siauw and Vertizon TV channels. The YouTube Data Tools application is used to explore the various elements in each video. This application is an online application created by Bernhard Rieder containing a collection of tools to extract data from the YouTube platform via YouTube API v3. ${ }^{8}$ This application helps me to find out data about videos, channels, and various comments on a post. Therefore, this study uses the help of various tools and methods so that it is expected to produce maximum results.

\section{Theoretical Approach}

In general, the term "mualaf" refers to a person who has the hope of becoming Islam or a person who has recently converted from another religion to Islam. ${ }^{9}$ There are certain periods of time when a person can be referred to as a "mualaf". This seems to be related to the social practice

8 Bernhard Rieder, "Research Software by Bernhard Rieder," accessed December 1, 2020, http://labs.polsys.net/.

9 Saftani Ridwan, "Ketertarikan Terhadap Islam ( Studi Kasus Muallaf Yang Memeluk Islam Dalam Acara Dakwah Dr . Zakir Naik Di Makassar )," Sulesana 11, no. 1 (2017): $1-18$, journal.uinalauddin.ac.id/index.php/sls/article/download/3543/3292\%0A. 
that occurs in Islam to help converts (mualaf) in both the maturity aspect of their faith and in the aspects of their economic life. These converts are one of the groups that need help, both spiritually through mentoring and economically through zakat (tithe or alms). ${ }^{10}$ In this article, the use of the term "mualaf" in the "da'i mualaf" is only limited to differentiate between preachers who have embraced Islam since their birth and preachers who have just embraced Islam as adults.

Religious conversions or changes in religion in plural societies such as Indonesia are common. There are many factors that cause a person to convert or change their religions, including various events, ideologies, institutions, expectations, and orientations. Lewis R. Rambo emphasized that conversion is not a single event but a process over time; is contextual and there is a matrix of relationships between expectations and situations that influence each other; and the causative factors are multiple, interactive and cumulative. ${ }^{11}$ In other words, religious conversion is a complex event and decision that occurs in a person to change his religious belief or institution.

John Lofland and Norman Skonovd, as quoted by Rambo, distinguish religious conversion in six motifs, namely intellectual, mystical, experimental, affective, revivalist, and coercive. ${ }^{12}$ First, on the intellectual conversion, a convert searches for various alternative knowledge about religion and spirituality through various literature, television, lectures, and other ways. Second, mystical conversion is more subjective in nature because it is based on sudden and traumatic bursts of insight caused by various visions, voices, and other paranormal experiences. Third, experimental conversion occurs as a result of active exploration efforts of religious choices, in which aspiring converters seek to find theological traditions, rituals and religious organizations that

10 See: Ita Umin, Umi Aisyah, and Rini Setiawati, "Bimbingan Agama Islam Bagi Muallaf Di Muallaf Center Indonesia (MCI)," Bina Al-Ummah 14, no. 2 (2019): 139; Another of the five pillars required of Muslims, zakat is a tithe that is to be paid each year by all Muslim adults in the amount of $2.5 \%$ of their income and wealth. Richard C. Martin, Encyclopedia of Islam and the Muslim World, ed. Richard C. Martin (New York: Macmillan Reference USA, 2004), 754.

11 Lewis R. Rambo, Understanding Religious Conversion (New Haven: Yale University Press, 1993), 5.

12 Rambo, 14-16. 
match their needs. Fourth, affectional conversion emphasizes interpersonal bonds that play an important role in the conversion process, where a person feels loved, nurtured, and strengthened by a group and its leaders. Fifth, revivalism conversion occurs as a result of the transformation of a person who is successfully influenced by one particular group so that he/she has a strong emotional attachment to his/her new belief. And the sixth conversion motif is coercive which occurs because of coercion or pressure on someone to participate in and follow certain religious groups.

Religious conversion may be an advantage for the new religion that is entered. Perhaps this can also be understood as the success of religious mission or da'wah. They succeeded in influencing someone to join their religion. In the context of Islam, there is a paradigm which views that the purpose of da'wah is Islamization, that is, the conversion of one's religion from another religion to Islam. ${ }^{13}$ Da'wah can be understood as the missionary aspect of Islam in which Muslims encourage non-practicing Muslims to practice again (or practice according to a particular ideological view) and encourage non-Muslims to convert to Islam. ${ }^{14}$ Even though this paradigm has been largely abandoned, there are still some people who consider the conversion of a person as a measure of the success of da'wah. This mindset also occurs in other religions besides Islam.

From this paradigm, religious conversion can be seen as the result of efforts to convey religious discourse in the community which ultimately succeed in attracting someone to join it. Viewed from the perspective of Habermas's theory of public sphere, da'wah activities can be interpreted as an attempt to contest religious discourse in the public sphere of society. In this case, religion as an element of society is part of the opinion raised in the public sphere, which has the same place as

${ }^{13}$ See: A Ilyas Ismail, The True Da'wa: Menggagas Paradigma Baru Dakwah Era Milenial (Jakarta: Prenadamedia Group, 2018), 47; Johan Meuleman, "'Dakwah', Competition for Authority, and Development," Bijdragen Tot de Taal-, Land- En Volkenkund 167, no. 2/3 (2011): 236.

${ }^{14}$ Martin, Encyclopedia of Islam and the Muslim World, 750. 
various other elements of society in the public sphere of society. ${ }^{15}$ Religious communities, especially those who actively take part in the dissemination of religious teachings, play a major role in building religious discourse in the public sphere of society.

In this era of social media, the public sphere as a place to exchange opinions and discourse has shifted to a virtual space accommodated by various social media platforms. As highlighted by Van Dijck, social media is a media platform that allows people to make connections by sharing expressive and communicative content each other, building professional careers, and enjoying online social life. ${ }^{16}$ Following Habermas's view of the public sphere, social media is a public sphere that becomes an autonomous space for the dissemination of public opinion. ${ }^{17}$ It is the cyber sphere, a complex place, in which there are various things, including as a place for self-representation, but also as the "safest place" to hide human motivation. ${ }^{18}$

It is through social media that users can easily participate, share, and create content, for example blogs, wikis and forums. They can also communicate by exchanging messages, sharing, networking, commenting and even debating on it. The various activities that can be carried out by social media users show how this new media has shaped a participatory culture in the media. According to Jenkins, participatory culture is emerging as the culture absorbs and responds to the explosion of new media technologies that make it possible for average consumers to

${ }^{15}$ See: Jürgen Habermas, "Religion in the Public Sphere," European Journal of Philosophy 14, no. 1 (2006): 1-25.

${ }^{16}$ Jose van Dijck, The Culture of Connectivity: A Critical History of Social Media (New York: Oxford University Press, 2013), 4.

17 For Habermas, the public sphere should be an autonomous space different from the state and the market, which does not exist from administrative power or capitalist economy. The public sphere is a specific part of civil society, as the term Öffentlichkeit (Germany) originates, which means "a condition accessible to all people". In tracking the term "public sphere", Habermas did not find a term that was earlier than this term in German. So Habermas concluded that the term "public sphere" in German which appeared in the 18th century was first used in a German context. See: Jürgen Habermas, The Structural Transformation of the Public Sphere: An Inquiry into a Category of Bourgeois Society, 5th ed. (Cambridge: The MIT Press, 1993), 2-3.

${ }^{18}$ Leonard Epafras, "Religious E-Xpression among the Youths in the Indonesian Cyberspace," Jurnal ILMU KOMUNIKASI 13, no. 1 (2016): 6. 
archive, annotate, appropriate, and recirculate media content in powerful new ways. ${ }^{19}$

The activities of social media users will eventually intersect with various opinions and religious discourses that exist on various social media platforms. As social media users, the public can not only access various existing religious discourses, but they can also play an active role in spreading various opinions and discourses on social media. People can freely choose what content they want to access according to their wants and needs. Meanwhile, for content creators, this is an opportunity to contest in order to attract as many people as possible to access the content they produce on social media.

Therefore, da'wah activities in social media are actually not just distributing contents of religious discourse. There are so many aspects that must be considered in order to attract public attention. In this case, religion and sacred teachings, as referred to by McAlexander et al, underwent "marketization" and "detraditionalization" efforts in which both were placed as commodities. ${ }^{20}$ The actors try to make religion and the religious teachings they spread get the attention of the community and have a broad influence on society. So, the marketing strategy needs to be used like a trader who wants to sell his merchandise. In this perspective, the popularity of the da'i mualaf who are often found through social media can be understood as their success in packaging and offering religious messages to the public.

\section{Da'i Mualaf and The Story of Their Conversion}

From a number of accounts that uploaded lectures given by a number of da'i mualaf, I got several stories of their conversion, both their motivation and their background to convert. Getting these stories is not difficult because generally the admins of the channel will provide video titles that are directly related to the content of the lecture delivered. The provision of an attractive title is an important part of getting the attention

\footnotetext{
${ }^{19}$ Henry Jenkins et al., Confronting the Challenges of Participatory Culture: Media Education for the 21st Century (London: The MIT Press, 2009), 8.

${ }^{20}$ James H. McAlexander et al., "The Marketization of Religion: Field, Capital, and Consumer Identity," Journal of Consumer Research 41, no. 3 (2014): 239.
} 
of netizens to view their content. So, giving this title is also a marketing strategy that must be carried out by YouTubers, the term for YouTube content creators.

Two short stories of da'i mualaf that I give below are examples of the type of conversion that Rambo calls as tradition transition conversion, in which the two figures move from one religious institution to another. ${ }^{21}$ As I mentioned before, the two da'i mualaf discussed here are Ustadz Felix Siauw and Ustadz Steven Indra Wibowo. Based on the conversion motif as previously mentioned, the conversion of the two da'i mualaf can be categorized into intellectual and experimental conversion motifs. In this case, to get the picture I will briefly describe the story of each person. Their story is revealed in several da'wah videos which can be found on YouTube.

Ustadz Felix Siauw. In several lectures uploaded on YouTube, both by private official channels and re-uploaded by other channels, he often talks about his struggles before establishing himself to embrace Islam. He was born and raised in a Catholic family. Even his primary and secondary education was carried out in Catholic schools. In his life, he experienced struggles about his faith. He often asks about his existence as a human being: where did he come from, why live in this world, where do humans after death? Unable to find answers to these questions in his previous religion, he had established himself as an atheist - a person who did not believe in God and later became an agnostic, who believed in God but was not affiliated with any particular religion. In the next time, an encounter and dialogue with an ustadz (teacher) was able to change his perspective on life. He found answers to those three questions in Islam. According to him, Islam provides a definite answer compared to other religions. ${ }^{22}$

${ }^{21}$ Rambo, Understanding Religious Conversion, 14.

22 A full explanation can be seen in the video lecture entitled "Alasan @FelixSiauw Masuk Islam" (The reason @FelixSiauw has entered Islam) which was uploaded on the YouTube channel 'Felix Siauw' which was uploaded on September 7, 2017. When the author accessed it, this video had been watched 203,455 times. Apart from this video, Felix Siauw also shares his conversion story in other lectures and has been uploaded on various channels. We can easily find it in the YouTube search field by entering keywords, for example: "Kisah Ustadz Felix Siauw" (The story of Ustadz Felix Siauw) and other related keywords. See. Felix Siauw, "Alasan@FelixSiauw Masuk 
Ustadz Steven Indra Wibowo. The story of Steven Indra Wibowo's conversion to Islam is told in many lecture opportunities. From his own statement when explaining the story of his conversion on various occasions, different and changing data are often obtained. Often there is an inconsistency between one story and another. His historical data are often considered dubious by many groups. ${ }^{23}$ Regardless of the pros and cons of his background, Steven Indra Wibowo admitted that his desire to convert to Islam was just for fun. He admitted that while still serving at the Jakarta Cathedral as a Catholic priest, one day he accompanied his friend to a mosque and expressed his desire to become a Muslim. And on the same day, he pronounced the shahada, the Muslim profession of faith. Even after becoming a Muslim, he still continued his ministry as a priest until the next half year he applied for a resign as a priest. Since then, he started studying Islam. In 2003, after returning from Umrah, he and several friends founded the Mualaf Indonesia (Indonesian Mualaf) which is now named the Mualaf Center Indonesia (Indonesian MualafCenter). ${ }^{24}$

It seems that the two stories have become a special attraction among the community, especially Muslims. Unfortunately, we don't know how they studied Islam after their conversion. So far, I don't get any data

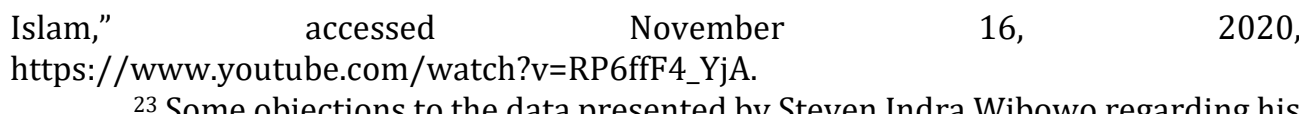

${ }^{23}$ Some objections to the data presented by Steven Indra Wibowo regarding his background as a former pastor have been made by the Komisi Komunikasi Sosial Keuskupan Agung Semarang (Semarang Archdiocese of the Social Communication Commission). See. KOMSOS Keuskupan Agung Semarang, "Fakta: Tidak Ada Nama Rm. Steven Indra Wibowo SJ Di Gereja Katedral Jakarta," accessed November 18, 2020, https://www.youtube.com/watch?v=gfXIt7dY5kY; KOMSOS Keuskupan Agung Semarang, "Sadisnya Data: Tidak Ada Nama Rm Steven Indra Wibowo SJ Di Data Provinsialat SJ Indonesia," accessed November 18, 2020, https://www.youtube.com/watch?v=MgqcImm7X7s.

${ }^{24}$ I summarize this information from a number of videos, including: Vertizon TV, "Sharing Sesion Dengan Koh Steven Di Magelang," accessed November 17, 2020, https://www.youtube.com/watch?v=t2c_c3BTWb8\&list=WL\&index=6; Vertizon TV, "Belajar Sholat Di Dalam Gereja - Koh Steven Indra Wibowo Berbuat Baiklah Kepada Sesama," n.d., https://www.youtube.com/watch?v=38ESFmsaANU\&t=340s; Vertizon TV, "Kisah Mualaf Koh Steven Indra Wibowo - Masjid Bukit Baruga Antang," accessed November 16, 2020, https://www.youtube.com/watch?v=7kkuMtnoIfg\&t=31s; Vertizon TV, "Hanya ISENG Masuk Islam, Pengalaman Koh Steven - YouTube," accessed November 27 , 2020 , https://www.youtube.com/watch?v=35qBN8pqNpg\&list=WL\&index=6. 
related to the transition period from a convert to becoming a $d a^{\prime} i$ or a religious preacher. This is an opportunity for further research.

\section{Accessing Online Da'wah Conveyed by Da'i Mualaf}

The development of social media with its various platforms gave birth to new ways of spreading religious teachings. In this case, da'wah is not only given from the pulpits of mosques, or rooms with limited capacities. The presence of social media also helps to disseminate religious lectures as if they are not limited by space and time. The public can freely choose and access the figure of the speaker and the topic of the lecture delivered. They can access various da'wah without being limited by time and space. Even with communication tools, such as smartphones or laptops, they can listen to religious lectures while doing various other activities. They can determine for themselves the appropriate time to access it.

The presence of da'i mualaf has also contributed to color religious discourse on social media. By utilizing social media, especially YouTube, they participate in spreading Islamic teachings. Even some of these $d a^{\prime} i$ mualaf quickly gained popularity in the community, which was marked by the large number of accesses to the da'wah they uploaded. It seems that their background as converts also contributed to their popularity. The conversion stories they share in their da'wah are an attraction for others to listen to and access their preaching. It can be said that the conversion story is an advantage for them.

In this section, I discuss the responses of the people who access da'wah conveyed by da'i mualaf through various social media platforms. First of all, we look at the responses of the questionnaire respondents, including their motivation to access and their impact on their religious life. In the next section, we examine the dynamics that occur in the scope of social media itself. I explore the various responses of netizens to the story of the conversion of these preachers. This search effort is carried out by reading netizens' comments on da'wah content. In particular, I explore two contents which contain the conversion story of Felix Siauw and Steven Indra Wibowo. So, the two parts that are discussed below are 
expected to complement each other in an effort to see the public response to the presence of da'i mualaf.

\section{Access to the Da'i Mualaf Da'wah: Motivation and Its Impact on Religious Life}

Responding to the question about how the respondents got information about the da'i mualaf on YouTube, a number of respondents admitted that they purposely looked for the $d a^{\prime} i$ mualaf because they had heard their story before. This means that there is an active role and a sense of curiosity that motivates respondents to access a lecture delivered by a da'i mualaf. There are also those who know the figure of a da'i mualaf from social media platforms and other sources of information, such as books, websites, and friends. Another respondent stated that they had attended da'wah that was delivered directly by da'i mualaf. In addition, there are also those who accidentally get it because content about da'i mualaf appears on their YouTube homepage.

Curiosity about the background of the da'i mualaf life and their story of getting hidayah ${ }^{25}$ was a factor that prompted many respondents to listen to the da'wah of the da'i mualaf. Most of the respondents hoped that by hearing the stories of the da'i mualaf, they would be strengthened in their faith. The background of the position and education of the $d a^{\prime} i$ mualaf in previous religions also became the main attraction for the respondents. The higher the position and religious education in the previous religion, the greater the respondent's interest in listening to the stories of the da'i mualaf. Another reason that arises is the desire to gain knowledge of the religions previously practiced by the da'i mualaf as a comparative study of religions. Some of them want to listen to the preaching because they know that the da'i mualaf do have good Islamic knowledge and education, regardless of their background as converts.

${ }^{25}$ Hidayah is an Arabic word meaning "guidance". According to Islamic belief, guidance has been provided by Allah to humans primarily in the form of the Qur'an. Not only through the Qur'an, but Hidayah, or guidance, is also provided through Muhammad, and how he lived his life, which is known as the Sunnah of the Prophet. Through his teachings and the guidelines in the Qur'an, Muslims hope to attain a better lifestyle. In the context of conversations about conversion, the word Hidayah is generally understood as an event when a non-Muslim is given guidance to convert their faith to Islam. 
Meanwhile, other respondents stated that their interest in accessing and listening to the da'i mualaf da'wah was due to their controversial figures and teachings in society.

After listening to da'wah from the da'i mualaf, particularly about their conversion stories, in general the respondents felt that they were increasingly affirmed as Muslims. In addition, they are also increasingly proud as Muslims and convinced that Islam is the true religion. This also encourages respondents to further deepen the teachings of Islam. However, there were also respondents who did not experience significant changes in their life of faith.

When narrating the conversion, da'i mualaf often mentioned their previous religious teachings. However, most of the respondents did not agree that da'i mualaf in their lecture discredited other religions that were previously practiced. Respondents were more interested in listening to the da'wah of preachers who had never discredited other religions. And if the da'i mualaf offended other religions, the respondents stated that they would not just accept the information they received and would still respect other religions.

From the answers of the respondents to the questionnaire, the presence of the da'i mualaf is considered to be able to make a positive contribution to their life of faith. In the aspect of faith, they are increasingly being strengthened through the conversion stories of the $d a^{\prime} i$ mualaf. Even so, the respondents remained critical of the preaching given by the da'i mualaf, especially those related to the teachings of other religions. In general, the respondents still respect other religions and do not just believe in teachings that discredit other religions when a preacher conveys them in their preaching.

\section{Netizens' Responses: From Admiration to Endless Debates}

The responses of netizens who accessed the da'wah video of the $d a^{\prime} i$ mualaf through the YouTube channel show various expressions and responses. In fact, there are often endless debates in the comment column. I will give two examples of the dynamics that occur among netizens by tracing the da'wah videos of Felix Siauw and Steven Indra Wibowo. In particular, I will look at the discussion that took place in the 
comments column on the video which contains the conversion story of the two da'i mualaf.

In the video entitled "Alasan @FelixSiauw Masuk Islam" (The reason@FelixSiauw has entered Islam), uploaded by Felix Siauw's official account on September 7, 2017, Felix Siauw explains his reasons for embracing Islam as his religion. Based on data generated via YouTube Data Tools for this post, this video has been viewed 205,150 times, liked by 5055 accounts, 165 dislikes and 341 comments. Meanwhile, the video "Hanya ISENG Masuk Islam, Pengalaman Koh Steven" (Just for Fun to Enter Islam, Experience of Koh Steven) uploaded by the Vertizon TV account on February 27, 2020, Steven Indra Wibowo mentioned his story of converting to Islam. This video has been viewed 11,930 times, liked by 600 accounts, disliked 17 accounts, and 118 comments. ${ }^{26}$ The comments on the two videos are quite varied, including expressions of admiration and praise, prayers and hopes, denials of the content of preaching and debates among netizens.

In general, netizens express expressions of admiration and praise in the comment column with short sentences and often no further discussion. For example, on both videos we can find a number of brief comments, such as: "Masyaallah" (by the will of Allah), "Subhanallah" (Holy God Almighty), "Terimakasih" (thank you), "Jenius" (Genius), "Alhamdulillah" (Thank God). Or comments that contain praise to the speaker, such as: "Ustat felix mang cerdas logikanya sangat diterima akal" (Ustadz Felix is really intelligent, his logic is very reasonable), "Ustadz cerdas terfavorit! Soalnya yg dibahas nggak cuma agama dari sisi spiritual tp dihubungkan juga dgn ilmu dunia" (My favorite smart Ustadz! He did not only discuss religion from a spiritual side, but connected it with world knowledge), "Semangat truss koh Steven. Barakallah Aamiin YRA" (Keep up the spirit, Steven. God bless you. Amen), "Paling seneng dengan kisah mualaf krn spt membuatku berkaca ttg keimananku. MashaAllah ak banyak belajar dari mualaf" (I like the story of converts the most because it can make me reflect on my faith. By the will of Allah, I have learned a lot

26 I browsed both videos using the YouTube Data Tool application on November 26, 2020. The application can be accessed on: Bernhard Rieder, "YouTube Data Tools," 2015, https://tools.digitalmethods.net/netvizz/youtube/. 
from converts). These comments show that netizens appreciate the presence of these da'i mualaf and also express support for them.

In line with the above expressions of admiration and praise, a number of netizens wrote comments containing prayers, both for themselves and for the da'i mualaf. For example, a prayer requesting that the da'i mualaf be given health and forgiveness of his mistakes, or the hope that he himself (netizen) will be enlightened to better understand Islamic teachings. This can be seen in several comments, such as: "Semoga ustd sll d beri Kesehatan" (May Ustadz always be given health), "Doa dan salamku utkmu ustadz, semoga slalu diberikan Rahmat kesehatan dan kebahagiaan beserta keluarga. Amin YRA" (Prayers and greetings to you Ustadz, I hope you and family are always given the grace of health and happiness. Amen), "Masyaallah... semoga usaha ko stevn utk umat selalu diberi kelancaran oleh Allah" (By the will of Allah, I hope that Steven's efforts for the people will always get smoothness from Allah". Meanwhile, there were netizens who prayed that people who hated da'i mualaf and the contents of the lecture would receive guidance and repent, for example: "Ya Alloh berilah Hidayah bagi orang2 yg menolak kajian Ustad Fellix" (O Allah, give hidayah to people who reject Ustad Fellix's preaching).

The type of comments that usually gets the most attention is the various denial comments about the content of the da'wah. This type of comment will provoke discussion and debate. In general, netizens will write critical arguments in the comment column. Meanwhile, there were those who made comments based on cynicism and hatred. It is clear that YouTube provides the freedom for netizens to share discourse and argument. I'll show examples of how the debate takes place in both videos.

In Felix Siauw's video we can see a number of intellectual debates. I call this an "intellectual debate" because much of the commentary is based on well-founded theological debate. For example, a netizen with the channel name Cleo $\mathrm{N}$ invited other netizens to think about a number of verses from the Al-Qur'an, Hadith, and the Holy Scriptures. He mentioned various quotations from the Al-Qur'an and Hadith which he considered contradicting each other, including verses containing the attitude of a Muslim towards other religious communities. In addition, he compared a 
number of verses from the Al-Qur'an and the Holy Scriptures regarding how the attitude of the faithful towards people who are considered as enemies. Furthermore, in the context of the theological debate about the figure of Jesus, which is often the subject of debate between Islam and Christianity, he mentions aspects of the divinity of Jesus as believed by Christians by mentioning a number of verses that affirm it, both the AlQur'an and the Holy Scriptures. Through this response, the Cleo N channel received various reactions from a number of other netizens, both support and denial. Unfortunately, there is no response from admin of Felix Siauw channel regarding this matter. This kind of commentary model also appears on the Vertizon TV channel.

I'll give a second example of this type by browsing the Vertizon TV video. I will discuss the response of netizens to Steven Indra Wibowo's conversion story. One of the critical responses that received many comments from other netizens came from the Brik Brik channel. At first this channel wanted to confirm Steven Indra Wibowo's family background. According to this channel, Steven's statements about his father's religion are inconsistent and confusing. Therefore, Brik Brik's channel wants to confirm whether his father, who is a Catholic, is also a member of the PGI (Association of Churches in Indonesia). As it is known, PGI is an organization whose members are Protestant Christian churches, while the Catholic Church has its own organization called KWI (Indonesian Bishops' Conference). This critical response then received various comments from other netizens, including defending Steven Indra. Unfortunately, there was no response from Vertizon TV.

Netizen responses to every video on YouTube shows that the public space in social media provides an opportunity for netizen to remain critical, although the debates and discussions are often never completed and not getting way out. Netizens are free to argue and engage in various debates and discussions, regardless of their background. There is no hierarchy that differentiates a person's social status in commenting and expressing opinions. Even without knowing each other, each of them can interact. There is one interesting thing that deserves attention, netizens who have the same ideology and religious views can actually have strong bonds with each other even though they don't know each 
other in the real world. The opposite can also happen, netizens who have different views and ideologies will continue to be hostile, which is manifested through comments that attack each other.

\section{Conclusion}

The presence of da'i mualaf in da'wah activities in Indonesia, especially through social media platforms, has contributed to the variety of Islamic discourses that can be accessed by social media users or netizens. The story of their conversion seems to be a basic asset that can attract people's attention to their existence in da'wah activities. This conversion experience is then supported by religious knowledge, both from previous religions and Islam itself. Although not many people know the background of their Islamic religious education after conversion, this does not really have an impact on society's acceptance of them. A number of da'i mualaf who are widely accessed by the public through social media, generally also have good public speaking skills so that they can attract people's attention. These are some of the supporting aspects of the popularity of the da'i mualaf.

The motivation of the people to access the da'wah conveyed by $d a^{\prime} i$ mualaf was quite varied. There are those who access it because they are curious about the conversion story of the da'i mualaf, but there are also those who listen to the da'wah because of the capable abilities of this figure. A number of netizens access the da'wah of the da'i mualaf because they just want to hear the story of the conversion of da'i mualaf, but there are also those who really want to learn from them.

The presence and preaching of da'i mualaf on social media have generated different reactions in society, especially social media users. Easily, we can see the 'like' and 'dislike' responses given by netizens on a post. This response can also be interpreted as two different attitudes from netizens towards them. Another response was given through comments, which showed that there were netizens who admired the figures and lectures delivered by da'i mualaf and there were also netizens who didn't like them. The first group generally provided various kinds of support and advocacy to them, while the other groups tried to criticize. Although there are differences in attitudes, especially among Muslims, the presence of 
da'i mualaf has been able to confirm the Islamic identity of the most of Muslims who access it.

\section{Bibliography}

Bahar, Komario. "Artis-Artis Yang Kabar Pindah Agamanya Bikin Heboh Di 2019." Accessed October 19, 2020. https://hot.detik.com/celeb/d-4776066/artis-artis-yang-kabarpindah-agamanya-bikin-heboh-di-

2019?_ga $=2.210545558 .2006997945 .1603072772$ 1064796533.1603072772.

Casanova, José. Public Religions in the Modem World. Chicago: The University of Chicago Press, 1994.

Dijck, Jose van. The Culture of Connectivity: A Critical History of Social Media. New York: Oxford University Press, 2013.

Epafras, Leonard. "Religious E-Xpression among the Youths in the Indonesian Cyberspace." Jurnal ILMU KOMUNIKASI 13, no. 1 (2016): 1-18.

Felix Siauw. "Alasan @FelixSiauw Masuk Islam.” Accessed November 16, 2020. https://www.youtube.com/watch?v=RP6ffF4_YjA.

Habermas, Jürgen. "Religion in the Public Sphere." European Journal of Philosophy 14, no. 1 (2006): 1-25.

- - - The Structural Transformation of the Public Sphere: An Inquiry into a Category of Bourgeois Society. 5th ed. Cambridge: The MIT Press, 1993.

Hasan, Noorhaidi. "The Making of Public Islam: Piety, Agency, and Commodification on the Landscape of the Indonesian Public Sphere." Contemporary Islam 3, no. 3 (2009): 229-50. http://files/185/s11562-009-0096-9.html.

Hew, Wai Weng. "The Art of Dakwah: Social Media, Visual Persuasion and the Islamist Propagation of Felix Siauw." Indonesia and the Malay World 46, no. 134 (2018): 61-79. https://doi.org/10.1080/13639811.2018.1416757.

Hine, Christine. Virtual Ethnography. London: Sage Publications, Inc., 2000.

Ismail, A Ilyas. The True Da'wa: Menggagas Paradigma Baru Dakwah Era Milenial. Jakarta: Prenadamedia Group, 2018. 
Jenkins, Henry, Ravi Purushotma, Margaret Weigel, Katie Clinton, and Alice J. Robison. Confronting the Challenges of Participatory Culture: Media Education for the 21st Century. London: The MIT Press, 2009.

KOMSOS Keuskupan Agung Semarang. "Fakta: Tidak Ada Nama Rm. Steven Indra Wibowo SJ Di Gereja Katedral Jakarta." Accessed November 18 , 2020. https://www.youtube.com/watch?v=gfXIt7dY5kY.

___. "Sadisnya Data: Tidak Ada Nama Rm Steven Indra Wibowo SJ Di Data Provinsialat SJ Indonesia." Accessed November 18, 2020. https://www.youtube.com/watch?v=MgqcImm7X7s.

Liputan 6. "Berita Deddy Corbuzier Masuk Islam Hari Ini - Kabar Terbaru Terkini | Liputan6.Com.” Accessed October 19, 2020. https://www.liputan6.com/tag/deddy-corbuzier-masuk-islam.

-_- "Tentang Kami." Accessed October 19, 2020. https://www.liputan6.com/info/tentang-kami.

Martin, Richard C. Encyclopedia of Islam and the Muslim World. Edited by Richard C. Martin. New York: Macmillan Reference USA, 2004.

McAlexander, James H., Beth Leavenworth Dufault, Diane M. Martin, and John W. Schouten. "The Marketization of Religion: Field, Capital, and Consumer Identity." Journal of Consumer Research 41, no. 3 (2014): 858-75.

Meuleman, Johan. 'Dakwah', Competition for Authority, and Development." Bijdragen Tot de Taal-, Land- En Volkenkund 167, no. 2/3 (2011): 236-69.

Nisa, Eva F. "Social Media and the Birth of an Islamic Social Movement: ODOJ (One Day One Juz) in Contemporary Indonesia." Indonesia and the Malay World 46, no. 134 (March 20, 2018): 24-43. https://doi.org/10.1080/13639811.2017.1416758.

Rambo, Lewis R. Understanding Religious Conversion. New Haven: Yale University Press, 1993.

Ridwan, Saftani. "Ketertarikan Terhadap Islam ( Studi Kasus Muallaf Yang Memeluk Islam Dalam Acara Dakwah Dr . Zakir Naik Di Makassar )." Sulesana 11, no. 1 (2017): 1-18. journal.uinalauddin.ac.id/index.php/sls/article/download/3543/3292\%0A.

Rieder, Bernhard. "Research Software by Bernhard Rieder." Accessed December 1, 2020. http://labs.polsys.net/. 


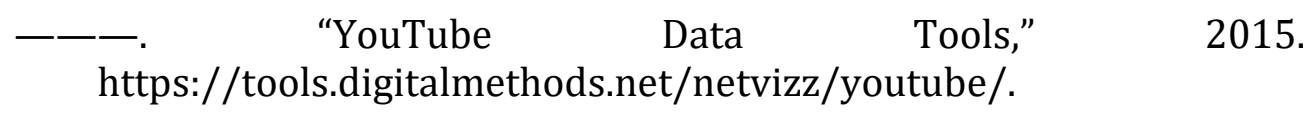

Slama, Martin. "A Subtle Economy of Time: Social Media and the Transformation of Indonesia's Islamic Preacher Economy." Economic Anthropology 4, no. 1 (May 22, 2017): 94-106. https://anthrosource.onlinelibrary.wiley.com/doi/abs/10.1002/se a2.12075.

Suharto, and Nurunnisa Mutmainna. "Dakwah Di Media Sosial Daring: Tinjauan Ceramah Khalid Basalamah Di YouTube." Al-Mishbah 14, no. 2 (2018): 191-203.

Umin, Ita, Umi Aisyah, and Rini Setiawati. "Bimbingan Agama Islam Bagi Muallaf Di Muallaf Center Indonesia (MCI)." Bina Al-Ummah 14, no. 2 (2019): 137-48.

Vertizon TV. "Belajar Sholat Di Dalam Gereja - Koh Steven Indra Wibowo Berbuat Baiklah Kepada Sesama," n.d. https://www.youtube.com/watch?v=38ESFmsaANU\&t=340s.

___. "Hanya ISENG Masuk Islam, Pengalaman Koh Steven - YouTube." Accessed November 27, 2020. https://www.youtube.com/watch?v=35qBN8pqNpg\&list=WL\&inde $\mathrm{x}=6$.

-_- "Kisah Mualaf Koh Steven Indra Wibowo - Masjid Bukit Baruga Antang." Accessed November 16, 2020. https://www.youtube.com/watch?v=7kkuMtnoIfg\&t=31s.

_—_. "Sharing Sesion Dengan Koh Steven Di Magelang." Accessed November 17 , 2020. https://www.youtube.com/watch?v=t2c_c3BTWb8\&list=WL\&inde $\mathrm{x}=6$. 